\title{
Sosialisasi Precision Farming untuk Monitoring Tanaman Perkebunan dan Hortikultura Kabupaten Jember
}

\author{
Bayu Taruna Widjaya Putra \\ Faculty of Agricultural Technology, University of Jember \\ bayu@unej.ac.id
}

\begin{abstract}
Abstrak
Kabupaten Jember merupakan daerah penghasil tanaman pangan dan hortikultura diantaranya yaitu kopi, kakao, edamame, tembakau dan beberapa komoditas lainnya. Petani di Kabupaten Jember masih menggunakan proses konvensional untuk mengelola pertanian. Mereka belum mengetahui teknologi yang dapat mendukung kegiatan pertanian menjadi lebih efisien. Teknologi pertanian presisi atau lebih dikenal dengan pertanian modern merupakan solusi untuk kegiatan pertanian menjadi lebih berkelanjutan. Sosialisasi pertanian presisi dilakukan untuk memberi gambaran dan pengetahuan awal kepada petani termasuk penyuluh pertanian dikabupaten Jember terhadap teknologi yang dapat dimanfaatkan dalam usaha pertanian. Kegiatan sosialisasi precision farming dilakukan pada bulan November 2018 di Dinas Tanaman Pangan dan Hortrikultura Kabupaten Jember. Kegiatan ini dihadiri oleh penyuluh pertanian kebupupaten Jember, beberapa petani dan perwakilan kelompok tani dari berbagai daerah di Jember. Rangkaian kegiatan yang dilakukan diawali dengan pengenalan alat atau instrumen yang digunakan dalam pertanian presisi. Kemudian petani serta penyuluh pertanian dipandu untuk menggunakan instrumen tersebut sehingga mereka dapat menerapkannya di lapangan. Luaran yang diharapkan dari kegiatan ini yaitu petani mampu secara mandiri maupun dengan kelompok taninya untuk menerapkan pertanian modern di lahan yang mereka kelola sehingga harapannya usaha pertanian yang mereka kerjakan akan lebih produktif.
\end{abstract}

Kata Kunci: Pertanian Presisi, Petani, Kabupaten Jember

\begin{abstract}
Jember is a region that produces food crops and horticulture including coffee, cocoa, edamame, tobacco, and several other commodities. Farmers in Jember Regency still use conventional processes to manage their farms. They do not yet know the technology that can support agricultural activities to be more efficient. Precision agriculture is an alternative solution to enhance farm productivities. The extension service related to precision agriculture was carried out to give an overview and initial knowledge (related to advanced technologies) to farmers through agricultural instructors. This activity was attended by agriculture instructors in the district of Jember and representatives of farmer groups from various regions in Jember. The output of this activity is that farmers can independently and with their farmer groups to implement advanced technologies related to agriculture to their farms.
\end{abstract}

Keywords: Precision Agriculture, Farmers, Jember 


\section{PENDAHULUAN}

Sektor pertanian di Indonesia hingga saat ini memegang peranan penting dalam perekonomian nasional. Peranan tersebut tidak hanya ditunjukkan dengan kontribusinya dalam PDB nasional, akan tetapi juga sebagai penyedia lapangan kerja, penyedia raw material untuk industri serta sumber pendapatan devisa yang berasal dari ekspor komoditas pertanian. Selain itu, sektor pertanian masih menjadi andalan sebagai sumber bahan pangan untuk kepentingan domestik (Setiawan, 2014). Sektor Pertanian dituntut untuk dapat memenuhi kebutuhan pangan penduduk yang diperkirakan akan semakin meningkat dari waktu ke waktu. Sementara itu penyempitan lahan pertanian menjadi kawasan perumahan dan industri merupakan salah satu dampak peningkatan jumlah penduduk (Pratiwi dan Rondhi, 2018).

Kabupaten Jember merupakan salah satu wilayah di Jawa Timur yang memproduksi beberapa komoditi petanian. Jember dikenal sebagai sentra kopi dan kakao, hal tersebut didukung oleh keberadaan Pusat Penelitian Kopi dan Kakao Indonesia yang berlokasi di Jember sebagai sentra komoditas kopi dan kakao dengan berbagai macam varietas. Pengelolaan yang dilakukan mulai dari budidaya hingga pasca panen. Selain komiditas kopi dan kakao, Jember juga memproduksi tembakau, edamame, karet dan beberapa komiditas lainnya. Akan tetapi, terdapat beberapa permasalahan pertanian di Kabupaten Jember yang meliputi luasan lahan pertanian semakin menyempit, hama dan penyakit tanaman dan penurunan kesuburan lahan karena dampak pupuk kimia yang berlebih (Putra dan Soni, 2020). Menurut Sunartomo (2015), Kabupaten Jember megalami konversi lahan pertanian akibat dampak dari pembangunan permukiman penduduk dan kawasan industri. Pada tahun 2005, luasan lahan pertanian di Kabupaten Jember yaitu 74.884,13. Pada tahun 2013, luasan lahan pertanian di Kebupaten Jember yaitu 74.229,26 Ha. Sehingga terjadi penurunan luas lahan pertanian di Kabupaten Jember dari tahun 2005 hingga 2013 seluas 654,87 Ha. Penurunan luasan lahan persawahan tersebut karena adanya peningkatan penggunaan peruntukan lahan lainnya. Pada Tahun 2005 luasan lahan peruntukan perumahan sebesar 34.427,41 Ha. Pada tahun 2013, luasan lahan peruntuhan perumahan meningkat menjadi 35.010,58 Ha (terjadi peningkatan sebesar $583,17 \mathrm{Ha}$ ).

Solusi tepat guna sangat dibutuhkan untuk menyelesaikan permasalahan pertanian yang terdapat di Kabupaten Jember. Pertanian Presisi (Precision Farming) merupakan solusi tepat guna untuk mencapai pertanian berkelanjutan, efisien serta meningkatkan produktivitas. Petanian presisi berguna untuk monitoring lahan, mendeteksi hama penyakit tanaman, dan mengestimasi kebutuhan pupuk tanaman (Anderson et al., 2016). Menurut Manalu (2013), Di negara-negara maju monitoring daerah pertanian dengan mengumpulkan input berupa data sumber daya pertanian secara kontinu, memproses dan menganalisis, kemudian menghasilkan output berupa informasi untuk keperluan manajemen secara praktis telah dilakukan sejak petengahan tahun 1980. Pertanian presisi dapat diterapkan pada berbagai tanaman budidaya, 
serealia, hortikultura, tanaman keras, dan peternakan (Sitthaphanit et al., 2009). Dalam aspek produksi, precision farming dapat meningkatkan efisiensi dan efektifitas pengelolaan lahan dari berbagai aspek seperti aspek agronomi, teknik dan ekonomi . Sedangkan manfaat bagi lingkungan yaitu dapat mengurangi pencemaran misalnya dengan peningkatan akurasi estimasi kebutuhan nitrogen sehingga dapat meminimalisir cemaran nitrogen yang terbawa run-off. Bagi petani, keuntungan yang didapat dari precision farming yakni akan terbentuk basis data akurat yang sangat berguna untuk mencatat data-data usaha tani dan hasil panen sehingga dapat membantu dalam pengambilan keputusan (Widjaja Putra dan Soni, 2017).

Petani di Kabupaten Jember masih memiliki pengetahuan yang minim terkait pertanian modern. Mereka masih menggunakan cara konvensional untuk mengolah lahan pertanian. Kurangnya pengetahuan petani terhadap teknologi merupakan salah satu faktor belum diterapkannya pertanian modern di Indonesia salah satunya di Kabupaten Jember. Oleh karena itu perlu dilakukan sosialisasi tentang pertanian modern dan pertanian presisi terhadap petani. Melalui sosialisasi yang dilakukan petani akan diberi pengetahuan awal untuk memahami pertanian modern dan penerapannya dilapangan sehingga harapannya mampu meningkatkan produktivitas usaha petanian.

\section{METODE PELAKSANAAN}

Kegiatan Penyuluhan ini dilaksanakan pada bulan November 2018 bertempat di Dinas Tanaman Pangan dan Hortikultura Kabupaten Jember. Peserta yang diundang dalam kegiatan meliputi penyuluh pertanian sekabupaten. Dalam kegiatan sosialisasi ini bekerjasama dengan PT. Precision Agriculture Indonesia yang merupakan perusahaan startup yang menggeluti usaha dibidang advanced technology untuk pertanian dan precision farming. Adapun tahapan dalam pelaksanaan kegiatan ini yaitu sebagai berikut:

\section{A. Perencanaan}

Dalam tahap ini, penulis menjalin kerjasama dengan PT. Precision Agriculture Indonesia bersama dengan Dinas Tanaman Pangan dan Tanaman Hortikultura Kabupaten Jember untuk melakukan kegiatan sosialisasi dan pelatihan untuk mengundang petugas penyuluh pertanian yang ada di kabupaten Jember untuk mengikuti kegiatan sosialisasi. Peserta dalam kegiatan yang dilakukan adalah petugas penyuluh pertanian setiap kecamatan di Kabupaten Jember, sehingga terdapat sebanyak 31 petugas penyuluh pertanian yang berpartisipasi dalam kegiatan sosialisasi yang dilakukan.

\section{B. Workshop}

Pada tahap workshop, penulis akan menyajikan materi tentang pertanian presisi, pertanian modern dan memberikan gambaran pertanian di negara-negara maju. Penulis 
menyampaikan pentingnya dan manfaat penerapan pertanian presisi untuk kegiatan pertanian yang berkelanjutan yang tentu akan sangat menguntungkan bagi petani dan juga lingkungan. Peserta workshop ini merupakan petugas penyuluh pertanian dari masing-masing kecamatan di Kabupaten Jember.

\section{Pelatihan}

Pada tahap pelatihan, penulis memberikan tutorial dan memandu peserta pelatihan tentang cara menggunakan beberapa alat atau instrumen yang dapat digunakan dalam pertanian presisi atau pertanian modern. Beberapa alat di antaranya yaitu SPAD chlorophyll meter dan Agriino (Mobile-Based Handheld Plant Nutrients Sensing System) serta beberapa alat modern lainnya untuk kegiatan pertanian.

\section{HASIL KEGIATAN}

Kegiatan penyuluhan precision farming untuk monitoring tanaman perkebunan dan hortikultura kabupaten Jember telah dilaksanakan di Kantor Dinas Tanaman Pangan dan Tanaman Hortikultura Kabupaten Jember. Kegiatan tersebut mendapat sambutan baik dari peserta yang sangat antusias sehingga kegiatan dapat berlangsung sebagaimana mestinya. Peserta kegiatan ini meliputi petani, penyuluh pertanian Dinas Tanaman Pangan dan Hortikultura Kabupaten Jember, kelompok tani kopi, kelompok tani tembakau dan beberapa kelompok tani komoditas lainnya. PT. Precision Agriculture Indonesia menjadi mitra dalam kegiatan penyuluhan kegiatan ini dengan menyediakan beberapa produk advanced technology for Agriculture yang dibuat untuk didemonstrasikan kepada peserta penyuluhan.

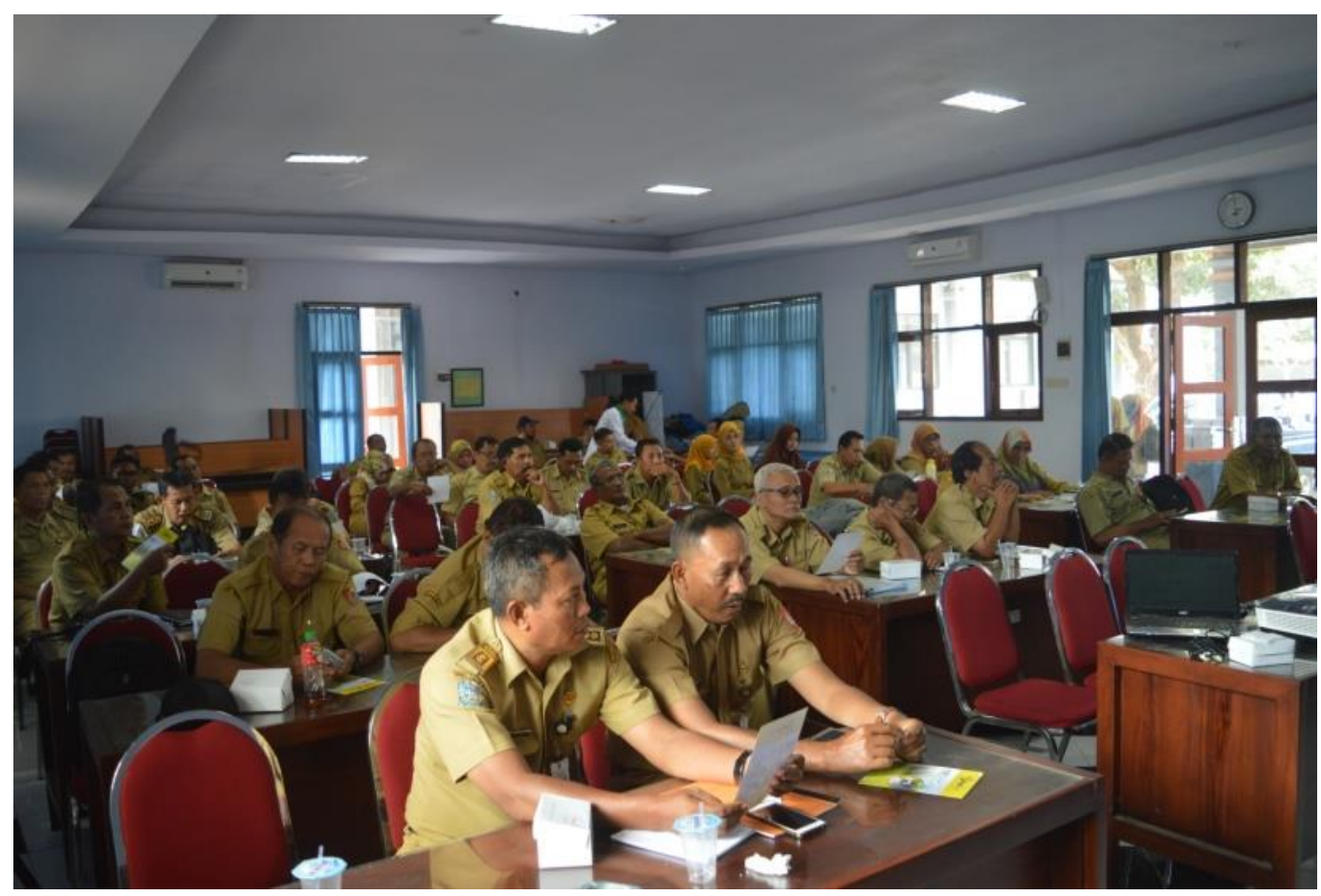

Gambar 1. Peserta Penyuluhan Precision Farming 
Kegiatan Penyuluhan ini diawali dengan penyajian materi pertanian presisi sehingga peserta penyuluhan mempunyai gambaran awal pertanian modern atau pertanian presisi seperti di negara-negara maju yang telah menerapkan drone untuk pemupukan otomatis, mendeteksi hama penyakit tanaman, mendeteksi keutuhan pupuk tanaman, traktor auto streering untuk melakukan pengolahan tanah dan beberapa advanced technology lainnya untuk pertanian. Precision farming yang memiliki orientasi site specific land management berupa measurement, analysis dan control, membutuhkan proses evaluasi dan analisa data dari semua data yang tersedia lalu memberikan rekomendasi penyelesaian yang harus dilakukan. Data yang dimaksud yaitu berupa data klimatologi, tekstur tanah, topologi lahan, dan data realtime yang didapatkan dari sensor.

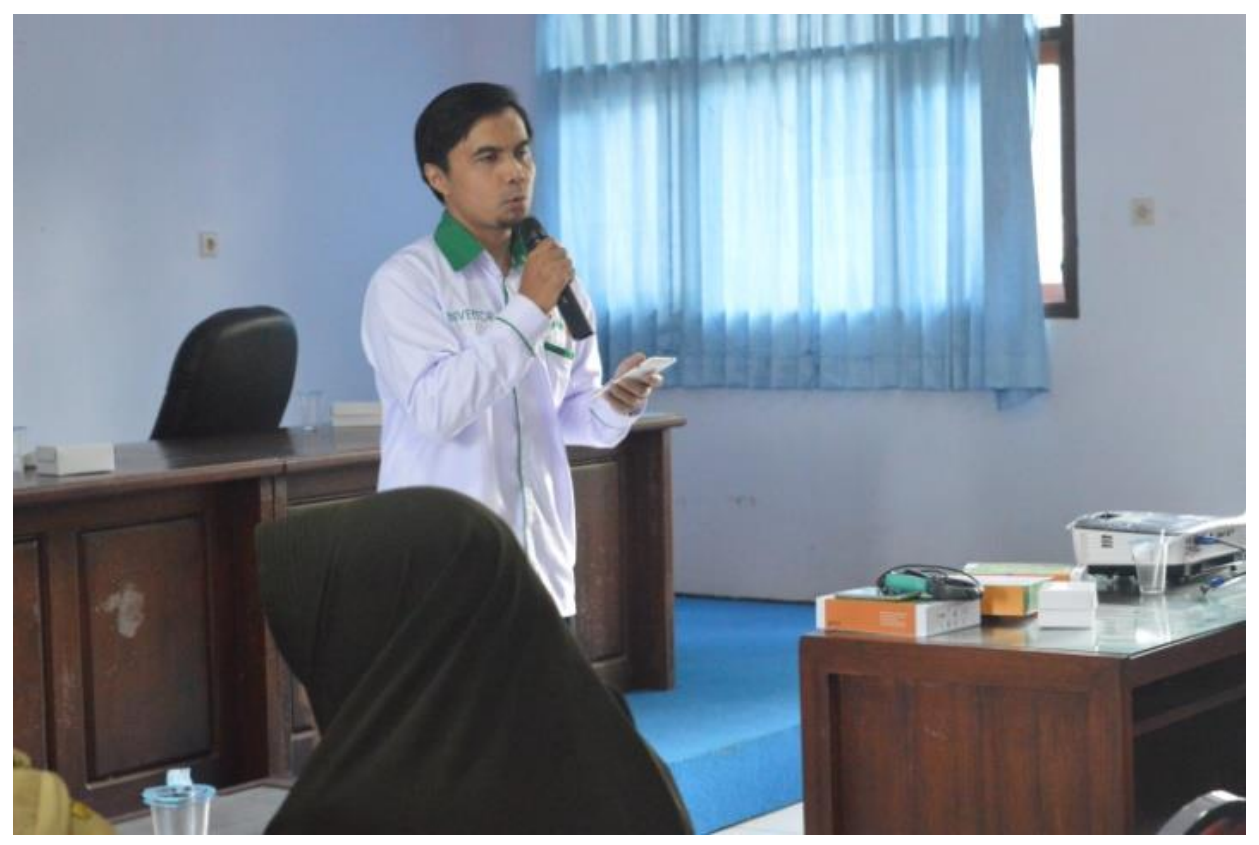

Gambar 2. Penyampaian materi Precision Farming

Dalam kegiatan ini tidak hanya dilakukan penyampaian materi saja, akan tetapi penyuluh juga memberikan training serta tutorial penggunaan alat atau instrument yang diguanakan dalam precision farming. Peserta penyuluhan dapat mendemonstrasikan alat-alat tersebut, adapun alat-alat yang dimaksud yaitu:

\section{A. SPAD Chlorophyll meter}

SPAD Chlorophyll meter adalah alat genggam (Portable) yang digunakan untuk mengukur konsentrasi klorofil daun secara cepat dan akurat serta bersifat undestructive pada daun. Cara menggunakan alat ini yaitu dengan menjepitkan bagian daun yang diukur diantara sensor. Harganya alat ini berkisar antara 2000-3000 USD. 


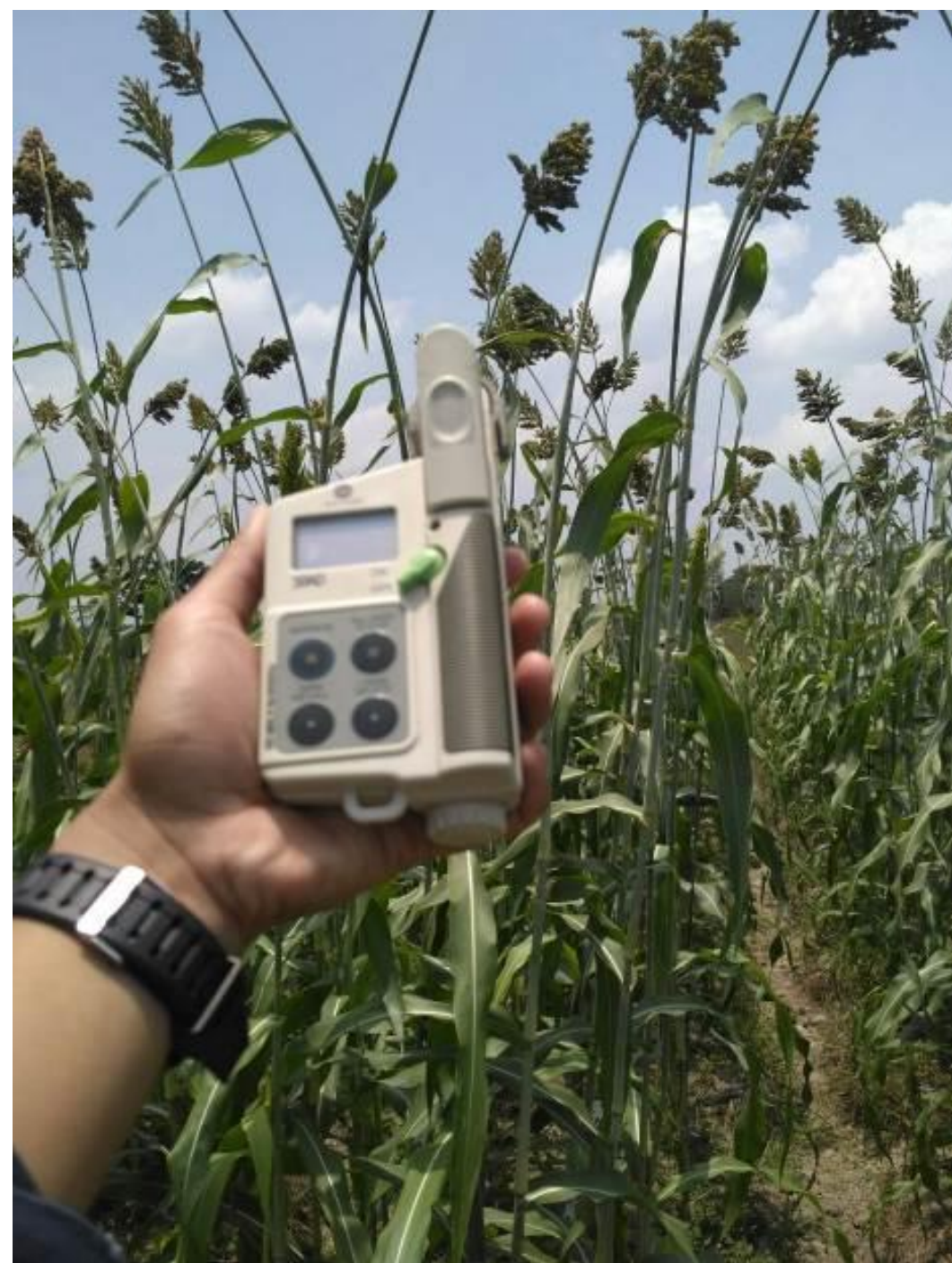

Gambar 3. Penggunaan SPAD Chlorophyll Meter di Lapangan

\section{B. Agriino (Mobile Based Handheld Plant Nutrients Sensing System)}

Agriino (Mobile Based Handheld Plant Nutrients Sensing System) merupakan salah satu alat yang diproduksi oleh PT. Precision Agriculture Indonesia untuk membantu petani dalam mengestimasi kebutuhan pupuk tanaman. Alat ini terdiri dari software dan hardware, software berbasis android dapat diunduh pada Google Play. Cara menggunakan alat ini hampir sama dengan SPAD Chlorophyll meter yaitu menjepitkan daun diantara sensor. Adapun fitur dari Agriino yaitu generate map, tanggal pengamatan atau pengukuran terrecord, dan dapat memberikan rekomendasi pemupukan sesuai dengan komoditi tanaman yang diukur. Harga Agriino berkisar antara 350USD. 


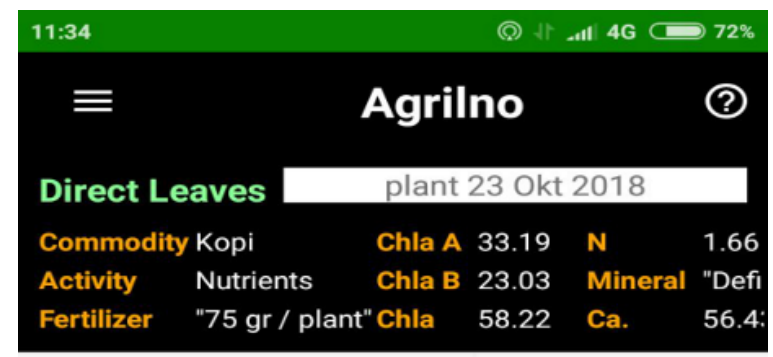

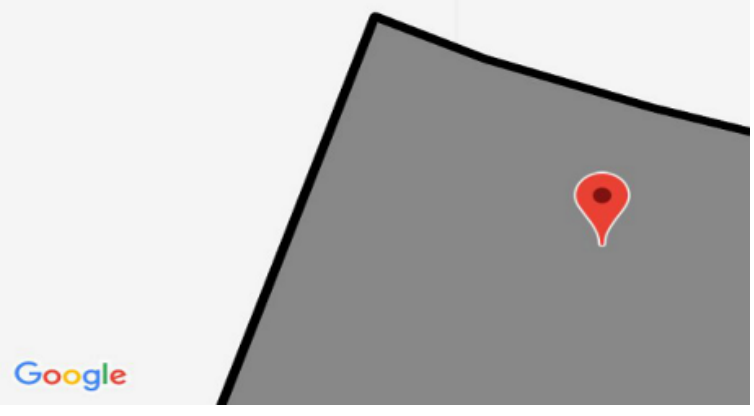

Gambar 4. Software AgriIno.

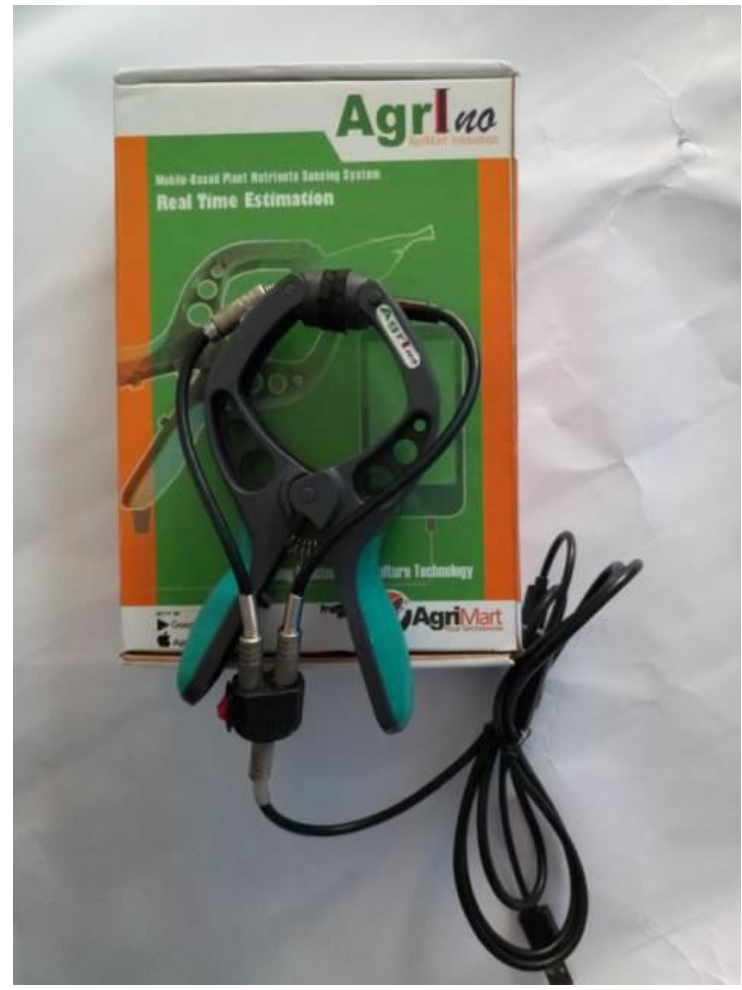

Gambar 5. Hardware AgriIno. 


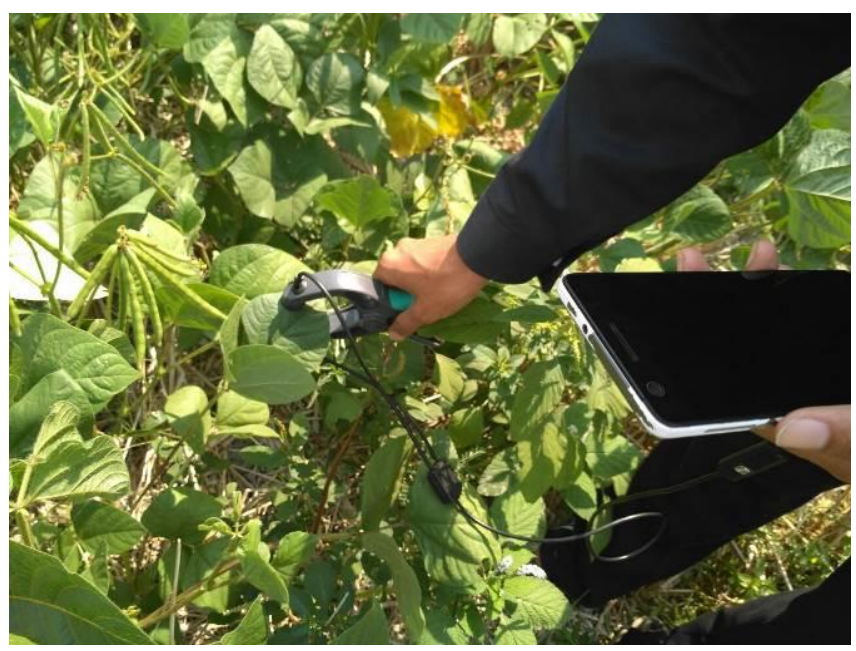

Gambar 6. Penggunaan Agrilno

Kegiatan ini tidak berakhir hanya sampai acara workshop selesai, akan tetapi penulis terus memberikan follow up kepada penyuluh pertanian Kabupaten Jember. Penulis juga sering diminta untuk sharing ilmu sebagai konsultan pertanian presisi. Harapannya penerapan pertanian presisi di Kabupaten Jember dapat mejadikan pertanian berkelanjutan dengan meningkatkan produktivitasnya.

\section{KESIMPULAN}

Berdasarkan hasil yang diperoleh dari kegiatan penyuluhan precision farming untuk monitoring tanaman perkebunan dan hortikultura Kabupaten Jember, kegiatan tersebut dapat menambah wawasan petani tentang pertanian presisi dan smart farming. Petani mampu mengoperasikan alat atau instrumen yang bersifat advanced technology for agriculture untuk di implementasikan di lahan mereka. Hal tersebut akan berdampak positif bagi petani dan juga lingkungan.

\section{SARAN}

Kegiatan pelatihan pertanian presisi ini dapat terus ditindaklanjuti dengan bermitra bersama perusahaan atau instansi yang bergerak dibidang pertanian sehingga tercipta pertanian yang ideal yaitu tidak hanya menguntungkan bagi petani akan tetapi mengurangi dampak negatif bagi lingkungan.

\section{DAFTAR PUSTAKA}

Anderson, H. B., L. Nilsen, H. Tømmervik, S. R. Karlsen, S. Nagai, dan E. J. Cooper. 2016. Using ordinary digital cameras in place of near-infrared sensors to derive 
vegetation indices for phenology studies of high arctic vegetation. Remote Sensing. $8(10)$

Manalu, L.P. 2013. Aplikasi Kontrol Digital untuk Pemupukan Secara Variabel Rate Pada Sistem Pertanian Presisi, JSTI, 15(3):31-38

Putra, B. T. W. dan P. Soni. 2020. Improving nitrogen assessment with an rgb camera across uncertain natural light from above-canopy measurements. Precision Agriculture. 21(1):147-159.

Pratiwi, P. A. dan Rondhi, M. 2018. Distribusi Kepemilikan Lahan dan Pendapatan Usaha Tani Di Wilayah Perkotaan Kabupaten Jember, SEPA, 15(1): 81-90.

Setiawan, A. 2014. Posisi Pertanian Yang Tetap Strategis Masa Kini dan Masa Depan. https://setkab.go.id/posisi-pertanian-yang-tetap-strategis-masa-kini-dan-masadepan/. [Diakses pada 02 Februari 2020].

Sitthaphanit, S., V. Limpinuntana, B. Toomsan, S. Panchaban, dan R. W. Bell. 2009. Fertiliser strategies for improved nutrient use efficiency on sandy soils in high rainfall regimes. Nutrient Cycling in Agroecosystems. 85(2):123-139.

Sunartomo, A. F. 2015. Pengembanan Konversi Lahan Pertanian diKabupaten Jember, Agrekonomika, 4(1):22-36.

Widjaja Putra, B. T. dan P. Soni. 2017. Evaluating nir-red and nir-red edge external filters with digital cameras for assessing vegetation indices under different illumination. Infrared Physics and Technology. 81:148-156. 